\title{
幽門形成術と胃十二指腸運動機能について
}

\author{
東邦大学医学部 外科学第二講座 \\ （主任：継 行男教授） \\ 橋 村千 秋
}

PYLOROPLASTY AND MOTILE FUNCTIONS OF THE STOMACH AND DUODENUM

\section{Chiaki HASHIMURA}

\author{
The Second Department of Surgery, Toho University, School of Medicine, Tokyo
}

(Director: Prof. Y. Tsugu)

Mongrel dogs were prepared by attaching 2 and 1 silver needle bipolar electrodes on the gastric antrum and bulbus of the duodenum, respectively. Among the obtained active potential from these dogs at chronic stage, investigations were performed mainly on the discharge frequency of spikes, propagation pattern of electrical excitation, and relationship of the stomach and duodenum. In addition, barium was loaded as the stomach contents and extraction dynamics of the loads were observed radiologically. The following was these investigations concerning about the pyloroplasty and motile functions of the stomach and duodenum.

Experimental methods

1) Electromyography and extraction dynamics of stomach contents were observed in no treated control dogs.

2) Heineke-Mikulicz type pyloroplasty, Finney type pyloroplasty, or pylorectomy was performed on the above described control dogs. Electromyographical comparison was made among the types of pyloroplasty.

3) Dogs subjected to selective vagolysis (SV), selective proximal vagotomy (SPV), or gastric transection ( $\mathrm{Tr}$ ) were divided into groups with and without pyloroplasty. Electromyography and extraction dynamics of stomach contents were observed in these groups of animals.

Results

1) In the control dogs, the mean discharge frequency of spikes in the gastric antrum at fasting time was $4.86 \mathrm{cycle} /$ minute. The spikes propagated to the pyloric side periodically. The discharge frequency of spikes was reduced by the load of stomach contents which took about 120 minutes to be extracted.

2) When the types of pyloroplasty were compared, smaller electromyographical changes were obtained in dogs subjected to Heineke-Mikulicz type pyloroplasty.

3) Pyloroplasty did not affect the discharge frequency of spikes at fasting time, whereas, high incidences of antiperistaltic propagation pattern of electrdcal excitation were observed in dogs subjected to SPV.

4) When stomach contents were loaded, drainage effects of pyloroplasty were suggested from the discharge frequency of spikes, propagation pattern of electrical excitation, and findings in extraction dynamics of the stomach contents. In the dogs subjected to SPV, pyloroplasty induced no significant fluctuations in the discharge frequency of spikes. Dogs subjected to $\operatorname{Tr}$ showed no improvement in the frequent antiperistaltic propagation pattern of electrical excitement after the pyloroplasty. 
5) By pyloroplasty, the frequency of simultaneous generation of spikes in the gastric antrum and duodenum was decreased in the SV and Tr groups, while it was increased in the SPV group.

\section{I. は じ め に}

胃十二指腸潰瘍の外科的治療として, 従来, 抒 もに胃切除術が施行されてきたが，欧米に扣い ては, 胃切除術の小胃症状あるいは gastric crippleなどの後遺症が問題となり, 胃の温存と いら点から迷走神経切離術（以下，迷切）が検 討されるよらになった。本邦に抢いても消化性 潰瘍に対しては, 迷切が減酸効果の面などから, より合目的な治療であるといら認識から検討さ れ，近年次第に普及してきた。しかし，迷切後 の合併症のひとつとして胃運動機能障害による 内容排出遅延があり, その対策として付加され る幽門形成術（以下，幽成）の効用については な怙不明な点が多い。この課題については諸家

\section{II. 実 験 方 法}

実験には，雑種成犬（体重 7 10 kg）を使用 し, Thiopental 静脈麻酔下に開腹し, 表 1 のよ らな実験群を作製した。対照群の汪かに幽成の 術式別比較をする目的で, 無操作胃に Heineke-Mikulicz 型幽成 (以下, HM 型), Finney 型 幽成（以下， $\mathrm{F}$ 型）抢よび幽門切除を施行した 実験犬を作製した。さらに迷切の術式別比較検 討群としては，SV，SPV，Tr だけを施行した非 幽成群と，これらを慢性期に同一犬で再開腹し 幽成を加えた幽成群に分けて検討した。

筋電図用の電極は銀針双極電極とし，極間距 離は $1 \mathrm{~mm}$, 極間抵抗は $50 \mathrm{~K} \Omega$ 以下とした。電 極の固定部位は表 $1 . I I の よ う に$ 胃前庭部に $\mathrm{E}_{1}$, $\mathrm{E}_{2}$, 十二指腸起始部に $\mathrm{E}_{3}$ の 3 個の電極を埋没 固定し, リード線は側腹壁を切開し腹腔外へ出 し皮下を通して右腰背部皮下に留置し随時活動 電位が導出できるようにした。増巾器は日本光 電 RM-5 型を使用し, 時定数は 0.03 秒とした。 筋電図の記録には Reticorder RJG 3004 型のペ
により実験的, 臨床的な検討がなされているが， 迷切の術式と幽成の関係については詳述された 成績は少なくない。そこで昭和 53 年以来著者 が, 選択的迷走神経切離術 (selective vagotomy 以下, SV), 選択的近位迷走神経切離術 (selective proximal vagotomy 以下, SPV) にそれ ぞれ幽成を付加した場合の運動機能の様相なら びに比較対象として胃角部で横切した胃横切 (gastric transection 以下，Tr)がなされた場合 の胃運動の変化と幽成の関係について，実験的 に消化管筋電図法ならびに一部 X線法により検 討した結果について述べる。

ンライターを用い, 記録紙速度は $10 \mathrm{~mm} / \mathrm{sec}$ と した。

実験に際しては, 前日より 24 時間絶飲絶食の 空腹状態として塩酸ヶタミン $10 \mathrm{mg} / \mathrm{kg}$ の筋注 麻酔下で活動電位の導出を行なった。活動電位 は空腹時と胃内容負荷後 3 4 時間にわたり連 続的に導出した。得られた筋電図パターンのな かでは扮もに放電頻度, 胃前庭部から導出され た活動電位の対応する 2 つのスパイク放電の伝 播性からみた興奮伝播様式，さらに胃の幽門前 部に抢ける放電と同期的に増強する十二指腸の 放電すなわち胃・十二指腸間の電気的活動の関 連について検討した。

胃内容排出動態の検討には, バリウム $100 \mathrm{~m} l$ の胃からの排出時間を経時的 (30 分毎) そレン トゲン透視下に観察した。この際, バリウム注 入後の minimum mucosal pattern が観察され るまでの時間を gastric emptying time (GET) とした。 
表1. 万法

I. 実験群

1. 対照群：無操作犬

2. 術式別比較検討群

(a) 非幽成群: SV, SPV, Tr. のみ

(b) 幽成群

SV

SPV +幽成 (Heineke-Mikulicz 型)

Tr.

II. 活動電位導出部位

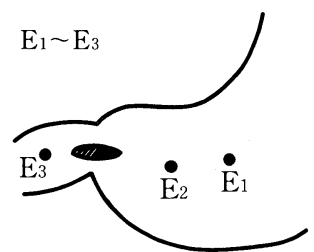

III. 観察項目

1. 筋電図学的検討（空腹時および胃内容負荷時）
（a）spike 放電頻度 （b）興奮伝播様式
(c) 胃と十二指腸の関連

2. 胃内容排出時間 (GET)

\section{III. 実 験 成 績}

\section{A. 筋電図学的検討}

1. 対照犬の筋電図 (図 1)

活動電位の導出は開腹術後 $1,2,3$ 週目にそ れぞれ行なった。対照犬に括ける空腹時の胃筋 電図パターンをみると，胃前庭部では平均 4.86 cycle/min の周期的な放電が観察され幽門側に 伝播する。この放電頻度は術後 1 週目では $4.58 \pm 0.05 \mathrm{cycle} / \mathrm{min}, 2$ 週目では $4.80 \pm 0.03$ cycle $/ \mathrm{min}$,さらに 3 週目では $4.86 \pm 0.19$ cycle/min で各時期間に有意差はないが, spike
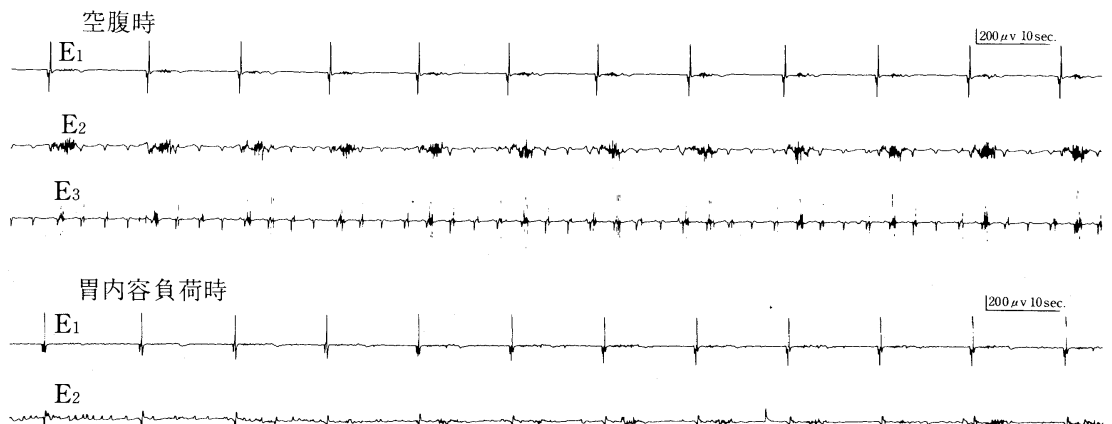

$\mathrm{E}_{3}$

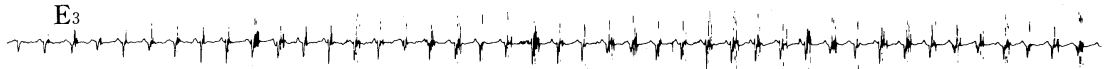

図 1. 対照犬の筋電図パターンをみると, 空腹時胃内容負荷時ともに胃前庭部には周期的な放電が観察 され幽門側に伝播するが，空腹時にくらべ胃内容負荷時の放電頻度は $10 \%$ 減少した. 


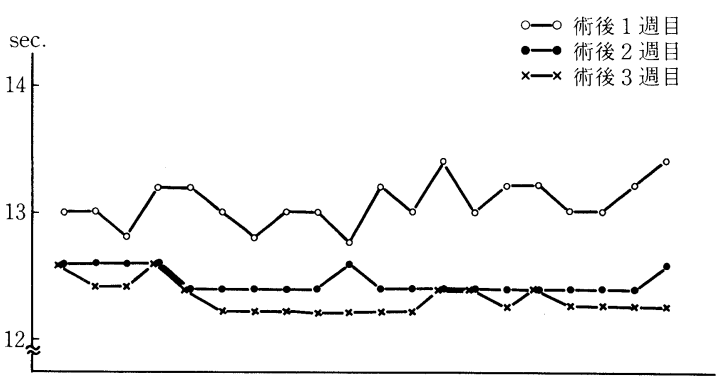

図 2. 開腹術後 1，2，3 週目の対照犬の胃前庭部の 放電間隔を diagramでみると次第に安定し ていく傾向がみられた。

放電の周期性は図 2 のように術後次第に安定し ていく傾向がみられ，興奮伝播様式でも逆蠕動 性放電様式の発現率は術後 1 週目で $3.6 \%, 2$ 週 目では $3.1 \%$,さらに 3 週目では $2.2 \%$ と減少 し, 開腹手術の影響は時間の経過とともに減少 する傾向がみられた。 また, 術後 1 ケ月以上に なると植込電極の腐蝕, 脱落などが生じやすく なるので開腹術後 3 週目頃がもっとも適当な時 期と判断し, 以下の実験はこの時期を選んで行 なった。

バリウム $100 \mathrm{~m} l$ を胃内容として胃ゾンデを 用いて注入負荷し, その 10 分後の放電頻度は平 均 $4.37 \mathrm{cycle} / \mathrm{min}$ で空腹時に対して $10.0 \%$ の 放電頻度の減少をみたが, 負荷後 20 分には投与 前の放電頻度に恢復し, spike 放電の周期性や 伝播速度には変化はみられなかった。また十二 指腸に扔ける活動期では平均 $19.13 \mathrm{cycle} / \mathrm{min}$ の頻度で spike 放電が観察されるが，この相は 休止期, spike が散発的に発生する時期ととも にいわゆる myoelectric complexを形成して 下方に伝播する。

2. 無操作胃に扮ける幽成の術式別比較（表 2，表 3)

幽成の術式としては HM 型，F型を採用し， この他に幽門機能の完全除去, 脱落といらこと に関して幽門切除（以下，幽切）犬を追加作製 し, 空腹時, 胃内容負荷時それぞれの筋電図学 的検討を行なった。

\section{a. 放電頻度}

空腹時の放電頻度は HM 型幽成の場合平均
表 2. 幽成の術式別比較（空腹時）

\begin{tabular}{l|c|c|c}
\hline & $\begin{array}{c}\text { Heineke- } \\
\text { Mikulicz }\end{array}$ & Finney & 幽門切除 \\
\hline $\begin{array}{l}\text { 放電頻度 } \\
(\mathrm{C} / \mathrm{min} .)\end{array}$ & $4.20 \pm 0.22$ & $4.65 \pm 0.05$ & $4.33 \pm 0.66$ \\
\hline $\begin{array}{l}\text { 逆蠕動性 } \\
\text { 伝播様式(\%) }\end{array}$ & 1.6 & 1.8 & 0 \\
\hline $\begin{array}{l}\text { 十二指腸との } \\
\text { 関連性 }(\%)\end{array}$ & 58.5 & 45.4 & 0 \\
\hline
\end{tabular}

表 3. 幽成の術式別比較（胃内容負荷時）

\begin{tabular}{l|c|c|c}
\hline & $\begin{array}{c}\text { Heineke- } \\
\text { Mikulicz }\end{array}$ & Finney & 幽門切除 \\
\hline $\begin{array}{l}\text { 放電頻度 } \\
(\mathrm{C} / \mathrm{min} .)\end{array}$ & $4.15 \pm 0.08$ & $3.75 \pm 0.29$ & $3.66 \pm 0.49$ \\
\hline $\begin{array}{c}\text { 逆蠕動性 } \\
\text { 伝播様式 }(\%)\end{array}$ & 0 & 2.0 & 0 \\
\hline $\begin{array}{c}\text { 十二指腸との } \\
\text { 関連性 }(\%)\end{array}$ & 81.4 & 58.0 & 0 \\
\hline
\end{tabular}

$4.20 \mathrm{cycle} / \mathrm{min}, \mathrm{F}$ 型幽成では平均 $4.65 \mathrm{cycle} /$ $\mathrm{min}$, 幽切では平均 $4.33 \mathrm{cycle} / \mathrm{min}$ で各術式間 に有意差はみられなかった。

胃内容負荷後の放電頻度は投与後 10 分では いづれも減少するが，HM型幽成の減少率は 1.1\% で， F 型幽成時の減少率は 19.3\% および 幽切時の減少率は $15.4 \%$ にくらべて低率で あった。ささらに胃内容負荷後の放電頻度を経時 的に検討すると, HM 型幽成では，投与後約 20 分で投与前の放電頻度に恢復したが，F型幽成 では投与後 20 分以降, 逆に放電頻度の増加がみ られ, 幽切犬では投与前の放電頻度に恢復する のに約 60 分を要した。

\section{b. 興奮伝播様式}

興奮伝播様式についてみると, 空腹時, 対照 犬に $2.2 \%$ 久られた逆蠕動性放電様式は，これ らに HM 型幽成付加時には $1.6 \%, \mathrm{~F}$ 型幽成を 付加した場合には $1.8 \%$ の頻度で逆蠕動性放電 様式の発現がみられたが，胃内容負荷により $\mathrm{HM}$ 型幽成では対照犬と同様にこの伝播様式 が消失したのに対し，F型幽成ではほとんど変 らず $2.0 \%$ の逆蠕動性放電様式がみとめられ た. 幽切時には, 逆蠕動性放電様式の発現は, 空 


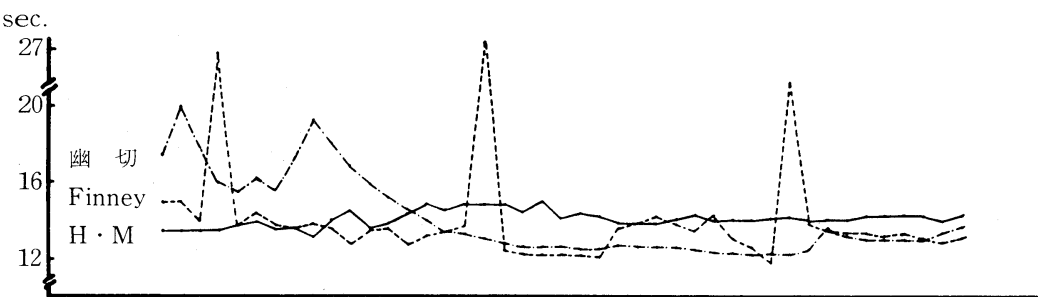

図 3. 空腹時の HM 型幽成, $\mathrm{F}$ 型幽成抢よび幽切時の胃の放電間隔を diagram でみると HM 型幽成が 他にくらべて規則的な安定したパターンを示した。

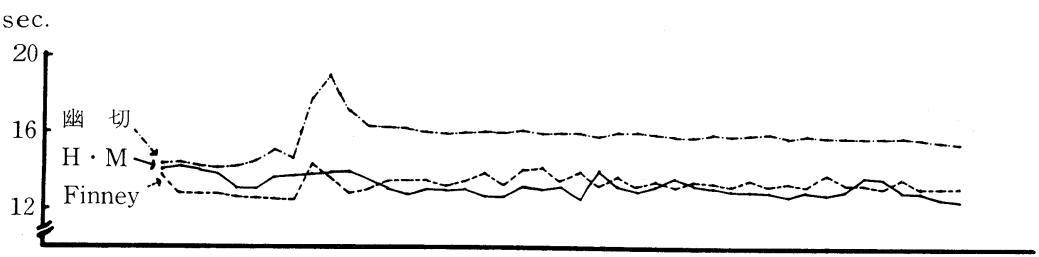

図 4. 胃内容負荷時においても, HM 型幽成が $\mathrm{F}$ 型幽成や幽切にくらべて規則的で安定したパターンを 示した.

腹時, 胃内容負荷時ともにみられなかった。

c. 胃と十二指腸の関連

胃と十二指腸の関連についてみると，空腹時 に HM 型幽成に $58.5 \% ， \mathrm{~F}$ 型幽成では $45.4 \%$ にみられた関連頻度は胃内容負荷により $\mathrm{HM}$ 型幽成で $81.4 \%$ と空腹時にくらべ $39.1 \%$ 増加 し， F型幽成ではこの頻度は $58.0 \%$ と空腹時に くらべ $21.1 \%$ 増加した。幽切時には, 空腹時, 胃 内容負荷時ともにこの胃と十二指腸の関連は今 回みとめられなかった。これら $\mathrm{HM}$ 型, F 型幽 成括よび幽切犬の空腹時放電間隔を diagram でみると，HM 型幽成に括いて他にくらべ規則 的な安定したパターンを示し, 胃内容負荷後も 同様であった（図 3, 図 4).

以上, 筋電図学的な幽成の術式別検討の結果, HM 型幽成が胃の電気的活動そのものに対し ては影響が少ないと判断され, 以降の実験には HM 型幽成付加時の迷切胃末たは横切胃に抒 ける胃十二指腸運動機能への影響について検討 した。

\section{B. 術式別比較検討}

1. 笳電図学的検討

a. 放電頻度

（i） 迷切時，横切時および幽成付加時の胃前 庭部の放電頻度.
空腹時, 無操作対照群の放電頻度は, 平均 4.86 $\mathrm{cycle} / \mathrm{min}$ で，これに幽成を付加しても平均 $4.20 \mathrm{cycle} / \mathrm{min}$ で非幽成, 幽成群の間に有意差 はみられなかった. SV 群では, 非幽成犬の放電 頻度は平均 $4.87 \mathrm{cycle} / \mathrm{min}$, 幽成犬では平均 $4.86 \mathrm{cycle} / \mathrm{min}, \mathrm{SPV}$ 群では, 非幽成, 幽成犬と もに放電頻度は平均 $5.37 \mathrm{cycle} / \mathrm{min}$ で, 空腹時 においては対照と迷切群の間に有意差は久とめ なかった。横切犬についてみると, 横切下部胃 では放電の周期性に乱れを生じ，後述するょう に逆蠕動性放電様式の多発によりスパイク数か ら算出する放電頻度は空腹時で平均 10.27 $\mathrm{cycle} / \mathrm{min}$ となり, 幽成を付加した場合には胃 前庭部の放電頻度は平均 $5.54 \mathrm{cycle} / \mathrm{min}$ で減 少を示した（表 4).

胃内容負荷時には，一般に胃前庭部の放電頻 度は減少するが，対照群では前述のごとく非幽 成犬では放電頻度の減少率は $10.0 \%$ で, 幽成付 加時にはその減少率は $1.1 \%$ となった. SV 群で も, 非幽成時, 胃内容負荷後 10 分の放電頻度は 平均 $4.31 \mathrm{cycle} / \mathrm{min}$ で空腹時の放電頻度にく らべ $11.5 \%$ 減少したが, 幽成付加時の胃内容負 荷後の放電頻度は平均 $4.80 \mathrm{cycle} / \mathrm{min}$ でその 減少率は $1.2 \%$ と対照犬と類似した結果であっ た。 
表 4. 各群に打忷る胃前庭部の放電頻度 $(\mathrm{C} / \mathrm{min})$ 空腹時

\begin{tabular}{l|r|r}
\hline & 非 幽 成 群 & 幽 成 群 \\
\hline 対 照 & $4.86 \pm 0.19$ & $4.20 \pm 0.22$ \\
$\mathrm{SV}$ & $4.87 \pm 0.05$ & $4.86 \pm 0.07$ \\
$\mathrm{SPV}$ & $5.37 \pm 0.09$ & $5.37 \pm 0.05$ \\
$\mathrm{Tr}$ & $10.27 \pm 6.67$ & $5.54 \pm 3.20$ \\
\hline
\end{tabular}

表 5. 各群に扮ける胃前庭部の放電頻度 $(\mathrm{C} / \mathrm{min})$ 胃内容負荷時

\begin{tabular}{l|c|c}
\hline & 非幽 成 群 & 幽 成 群 \\
\hline 対 照 & $4.37 \pm 0.07$ & $4.15 \pm 0.08$ \\
$\mathrm{SV}$ & $4.31 \pm 0.21$ & $4.80 \pm 0.16$ \\
$\mathrm{SPV}$ & $5.05 \pm 0.16$ & $5.09 \pm 0.14$ \\
$\mathrm{Tr}$ & $5.19 \pm 4.90$ & $4.02 \pm 2.66$ \\
\hline
\end{tabular}

一方, SPV 群では，胃内容負荷後の放電頻度 は非幽成群で平均 $5.05 \mathrm{cycle} / \mathrm{min}$ と空腹時の 放電頻度にくらべその減少率は $5.9 \%$ であり， 幽成付加時では放電頻度は $5.09 \mathrm{cycle} / \mathrm{min}$ で 空腹時にくらべて $5.2 \%$ の放電頻度の減少で非 幽成，幽成間に差はなく，幽成による影響はみ られなかった。

横切群の胃内容負荷後の放電頻度は，非幽成 犬では平均 $5.19 \mathrm{cycle} / \mathrm{min}$ で空腹時にくらべ 48.4\% の放電頻度の減少をみたが，幽成を付加 した場合, 胃内容負荷後の放電頻度は平均 4.02 $\mathrm{cycle} / \mathrm{min}$ と空腹時にくらべ $20.7 \%$ の減少が みられた（表 5).

（ii）各術式に拈ける胃内容負荷後の放電頻 度の経時的変動

$\mathrm{SV}$ 群では, 非幽成時, 胃内容負荷直後の放電 頻度の減少率は幽成付加時にくらべて大きい が, 負荷後 60 分経過すると空腹時の放電頻度に 恢復する。これに対して幽成群では，負荷直後 から内容負荷による放電頻度の減少率は低く経 時的に観察しても非幽成時より安定した経過を 示した（図 5).

SPV 群では，非幽成，幽成付加群ともに胃内 容負荷後 10 分では放電頻度は約 $5 \%$ 減少し両 者間に差はみられなかったが, 負荷後 60 分以降 では，非幽成時の放電頻度はさらに減少する傾

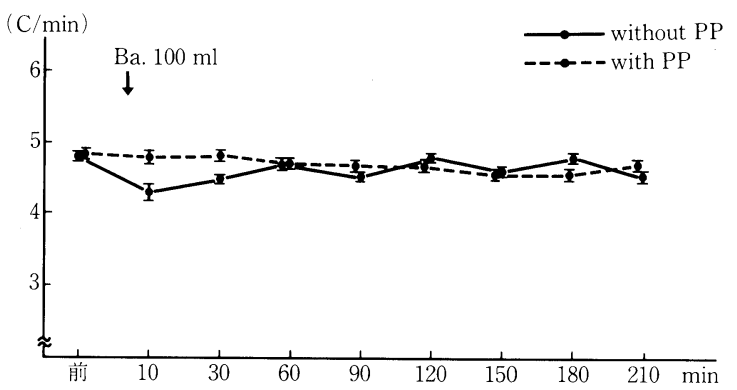

図 5. SV 群の胃内容負荷後の胃前庭部の放電頻度 は, 非幽成時にくらべ幽成時に安定した経過 を示した。

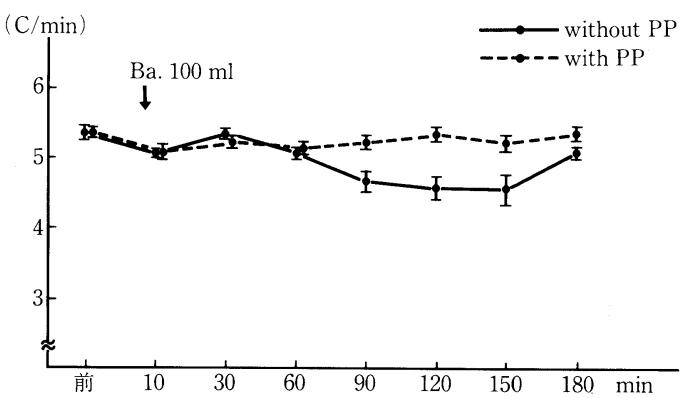

図 6. SPV 群の胃内容負荷後の胃前庭部の放電頻 度は非幽成時にくらべ幽成時に比較的安定 した経過を示した。

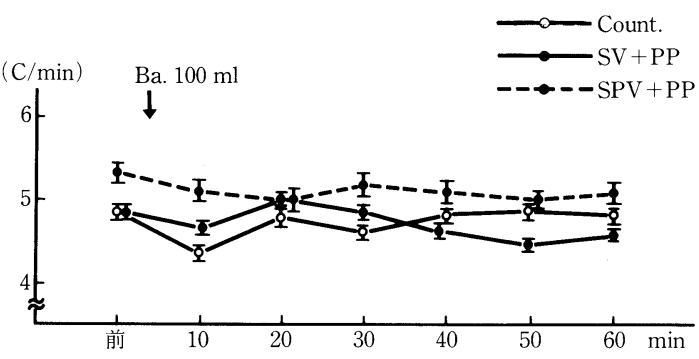

図 7. 対照群と SPV+幽成群の胃内容負荷後の放 電頻度の安定性にくらべ，SV+幽成群では 負荷後 60 分の時点での放電頻度の恢復はみ られなかった。

向を示したのに対し，幽成群では比較的安定し た経過を示した（図6）。

無操作対照群と迷切幽成付加群の胃内容負荷 時の放電頻度の経時的変動をみると，対照群と SPV 群では胃内容負荷後 20 30 分で比較的安 定化し, 負荷後 60 分で投与前の放電頻度に恢復 したのに対し，SV 幽成群では，投与後 60 分の 


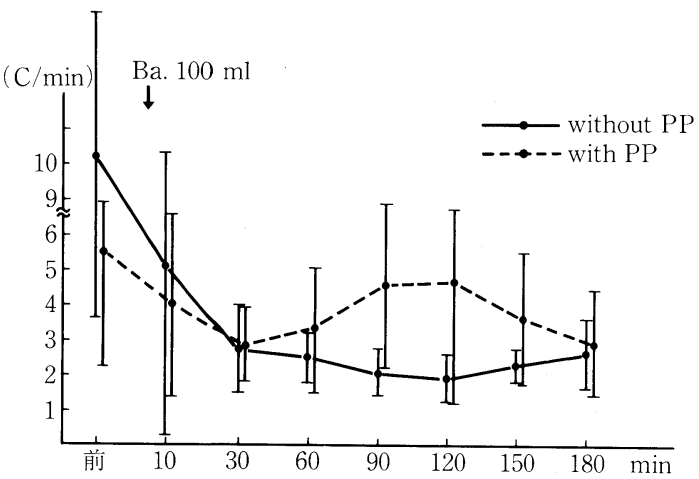

図 8. 横切群では迷切群にくらべて胃内容負荷直 後の放電頻度の減少率は著しいが, 幽成を付 加した場合には非幽成時と対称的に次第に 恢復する傾向を示した。

時点では放電頻度の恢復はみられなかった（図 7).

横切群では, 胃内容負荷後 10 分の放電頻度の 減少は非幽成，幽成犬とと女に迷切群にくらべ て著しく, 負荷後 30 分末で減少傾向は持続す る. 負荷後 60 分以降, 幽成犬では放電頻度が次 第に恢復する傾向にあり非幽成犬とは対称的な 経過を示した（戍8）。

\section{b. 興奮伝播様式}

逆蠕動性伝播様式の発生頻度についてみる と, 空腹時, 対照犬で $2.26 \%$ ，これに幽成を付加 した場合には $1.62 \%$ であるが，胃内容負荷によ り減少あるいは消失した。 SV 群では, 空腹時, 非幽成犬で $3.67 \%$ ，幽成犬では $2.09 \%$ と対照群
にくらべて逆蠕動性伝播様式の頻度はやや増加 を示したが，胃内容負荷により対照群と同様に この伝播様式の頻度は減少あるいは消失した。 SPV 群では, 空腹時, 非幽成犬の逆蠕動性伝播 様式の頻度は $0.70 \%$ と低いが，幽成付加時には 6.36\% と高率に発生した。しかし，これらは胃 内容負荷により前 2 群と同様に減少ないしは消 失した。横切群では, 空腹時, 非幽成犬では 16.08\%，幽成付加時には $31.31 \%$ の逆蠕動性伝 播様式が高頻度に発生した。これらは胃内容を 負荷しても非幽成犬で13.89\%, 幽成犬で $27.73 \%$ とやや減少はするものの対照群, 迷切群 にくらべて頻発する傾向を示した(図 9, 表 6).

c. 胃前庭部と十二指腸の電気的活動の関連 性について

胃と十二指腸のスパイク放電のパターンにつ いて観察すると，胃に打ける放電と同期的に十 二指腸にスパイク放電の発現や, 放電活性増強 などの所見がみられる場合があり，今回の実験 例では非幽成群 14 頭中 9 頭 $(64.2 \%)$, 幽成群で は 15 頭中 7 頭 (46.6\%)計 29 頭中 16 頭(55.1\%) にこの所見が観察された（図 10, 表 7).

これら関連を示す犬について胃と十二指腸に 打ける電気的活動の関連の頻度を観察時間内の 胃前庭部の全放電数から算出すると, 空腹時, 対 照群非幽成犬には $89.2 \%$ 又られた関連が幽成 を付加すると $63.0 \%$ と減少し, 胃内容負荷に よっても, 胃と十二指腸の関連の頻度は非幽成

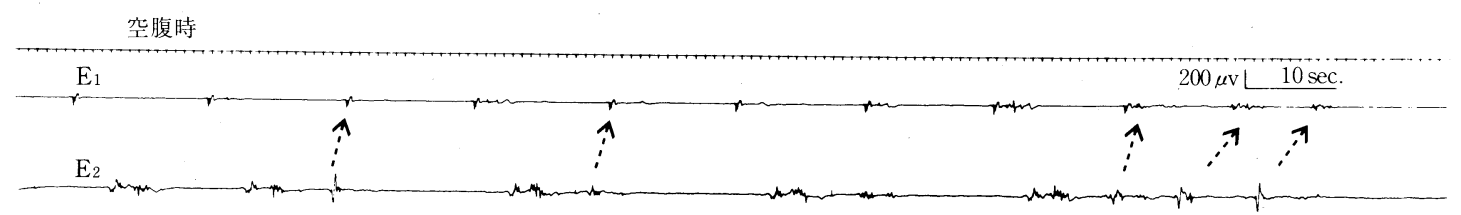

胃内容負荷時

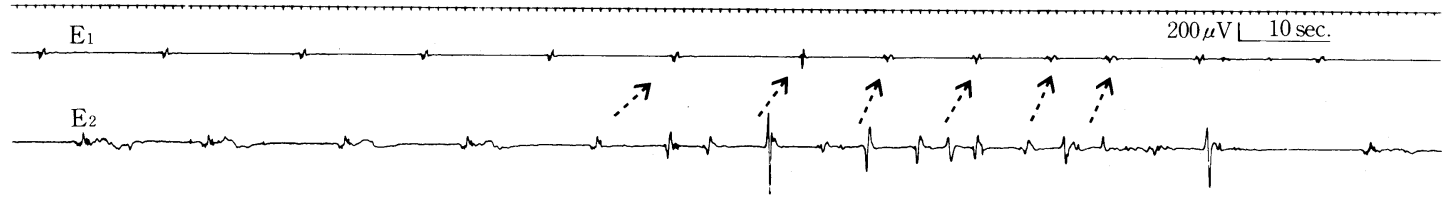

図 9. 胃前庭部の放電の伝播性の観察で, 時に一一のような幽門側から逆行するような伝播様式がみ られる場合かある。(SPV+幽成) 
$\mathrm{E}_{1}$

$\mathrm{E}_{2}$<smiles>[10BH]</smiles>

$E_{1}$

$\mathrm{E}_{2}$

$\mathrm{E}_{3}$

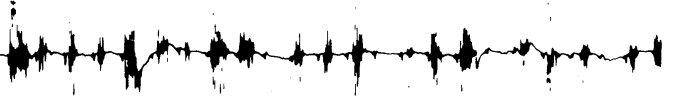

図 10。胃と十二指腸のスパイク放電のパターンの中で，胃に拈ける放電と同期的に十二指腸にスパイ ク放電の発現や放電活性増強などの所見がみられる場合がある。(SPV+幽成)

表 6. 逆蠕動性放電様式の頻度

$(\%)$

\begin{tabular}{l|c|c|c|c}
\hline \multirow{2}{*}{} & \multicolumn{2}{|c|}{ 非 幽 成 群 } & \multicolumn{2}{|c|}{ 凩成 群 } \\
\cline { 2 - 5 } & 空腹時 & $\begin{array}{c}\text { 胃内容 } \\
\text { 負荷時 }\end{array}$ & 空腹時 & $\begin{array}{c}\text { 胃内容 } \\
\text { 負荷時 }\end{array}$ \\
\hline 対 照 & 2.26 & 0 & 1.62 & 0 \\
SV & 3.67 & 0.84 & 2.09 & 0 \\
SPV & 0.70 & 0 & 6.36 & 0.74 \\
Tr. & 16.08 & 13.89 & 31.31 & 27.73 \\
\hline
\end{tabular}

表 7. 胃前庭部と十二指腸の電気的活動の関連性

(\%)

\begin{tabular}{c|c|c|c|c|c}
\hline & 対照 & SV & SPV & Tr. & 計 \\
\hline 非幽成 & 75 & 66.6 & 33.3 & 75 & 64.2 \\
\hline 幽 成 & 20 & 75 & 66.6 & 33.3 & 46.6 \\
\hline
\end{tabular}

犬で $68.8 \%$ ，幽成犬では $40.1 \%$ と減少した。

$\mathrm{SV}$ 群では, 空腹時, 非幽成犬に $55.4 \%$ みられ た関連が，幽成犬では $21.9 \%$ と減少した。これ らに胃内容を負荷した場合，非幽成犬で $39.8 \%$ ， 幽成犬では $35.6 \%$ の関連がみられ，SV 幽成群 で胃内容を負荷した場合に胃と十二指腸の放電 の関連の増加傾向がみられた。

一方, SPV 群では, 空腹時非幽成犬で $28.1 \%$
表 8. 胃前庭部ならびに十二指腸の関連

(\%)

\begin{tabular}{l|c|c|c|c}
\hline \multirow{2}{*}{} & \multicolumn{2}{|c|}{ 非幽 成 群 } & \multicolumn{2}{|c|}{ 幽成 群 } \\
\cline { 2 - 5 } & 空腹時 & $\begin{array}{c}\text { 胃内容 } \\
\text { 負荷時 }\end{array}$ & 空腹時 & $\begin{array}{c}\text { 胃内容 } \\
\text { 負荷時 }\end{array}$ \\
\hline 対 照 & 89.2 & 68.8 & 63.0 & 40.1 \\
SV & 55.4 & 39.8 & 21.9 & 35.6 \\
SPV & 28.0 & 25.0 & 46.9 & 49.1 \\
Tr. & 8.4 & 25.8 & 0.02 & 22.5 \\
\hline
\end{tabular}

表 9. 胃内容排出時間 (Ba. $100 \mathrm{ml})$

（分）

\begin{tabular}{l|c|c}
\hline & 非幽成 群 & 幽 成 群 \\
\hline 対 照 & \multicolumn{2}{|c}{120} \\
\hline $\mathrm{SV}$ & 210 & 180 \\
\hline $\mathrm{SPV}$ & 150 & 150 \\
\hline $\mathrm{Tr}$. & 210 & 210 \\
\hline
\end{tabular}

みられた関連が，幽成を付加すると $46.9 \%$ と増 加し，対照群やSV 群と対称的であった。しか し，これらに胃内容を負荷しても非幽成犬に $25.0 \%$ ，幽成犬では $49.1 \%$ と空腹時とくらべて も変化はみられなかった。

横切群では，空腹時，非幽成犬には関連所見 
は $8.2 \%$ ，幽成犬でも $0.02 \%$ と対照群や迷切群 とくらべて少なかったが，胃内容負荷によりこ の所見は非幽成犬で $25.8 \%$ ，幽成犬でも $22.5 \%$ と増加した（表 8).

2. 胃内容排出時間

無操作対照犬の GET は約 120 分であった が, SV 群では非幽成時の GET は約 210 分と延

\section{IV. 考}

従来，胃十二指腸の消化性潰瘍に対する外科 的治療の主流は, 胃酸分泌域の広範囲切除で あったが，近年，胃の温存，減酸を目的とした 迷切が検討され臨床的にも広く応用されるよう になった。迷切はD Dragstedt（1943）らによって 幹迷切（TV）が初めて報告されたが，本法は術 後の胃運動機能の低下による胃内容停滞が著し く、ひいては潰瘍再発などの問題もあった。こ の対策として Dragstedt（1945）が胃腸吻合を, Weinberg（1951）が幽成を提唱し，以来ドレ ナージ手術の付加が必要とされるようになっ た。迷切のうち TVは胃以外の臟器に分布する 神経も影響をらけることになることから，これ ら臓器への影響を考慮し Jackson \& Frankson （1948）が胃に分布する迷走神経の久を選択的に 切離し肝枝や腹腔枝を温存するSVを提唱した が，本法でも胃内容停滞はま奴がれずドレナー ジ手術の付加が必須と考学られるにいたった。 ついで，胃の運動機能を温存することが消化性 潰瘍の治療上重要であるといら考光から Holle \& Hart (1967) が減酸と同時に迷走神経の幽門 洞枝を温存して胃の排出能を保持しょうとする SPVを考案し比較的よい方法として応用され るようになった。しかし，一般的にはSPVにも 幽成が付加され，一方では Amdrup (1969) ら のように十二指腸に狭窄のない限り幽成は不要 とする研究者もあって SPV と幽成については 統一された見解はみられない交は推移してい る。本邦でも田北（1970）らが partial anterectomy $+\mathrm{SPV}$ を報告して以来, SPV 時の幽成 の必要性の有無や幽成の胃十二指腸へ抢よぼす 影響などについて検討されてさたが未だ充分に 解明されていない。
長し，これに幽成を付加した場合には約 180 分 々胃内容排出時間が約 $14.2 \%$ の短縮傾向を示 した。これに対し, SPV 群では, 非幽成, 幽成 犬ともに GET は約 150 分で幽成による影響は 又られなかった。横切群では, 非幽成, 幽成付 加時ともにGET は約 210 分と遅延し, 幽成付 加の影響はみられなかった（表 9).

\section{察}

一方, Wangesteen (1952) や大井 (1957) ら により高位潰瘍に対する術式として分節的胃切 除が報告, 検討されまた評価されてきた。しか し, 本邦でも当初は付加されなかった迷切や幽 成が切除範囲の縮少化や胃内容停滞などの問題 の解決のために付加されるようになり実験的, 臨床的に検討されてさた。幽成の術式として代 表的なものは, 幽門筋切開縦方向縫合の pyloroplasty を加光る Heineke-Mikulicz 型と, 胃と 十二指腸を吻合する Finney 型がある。これら の幽成が幽門狭窄の解除, 胃内容排出促進の効 果につながる一方で，幽成術自体による疫痕狭 窄あるいはダンピング症状などの合併症の要因 となることも報告され検討の余地を残している ことも事実である。

幽成型の別による検討については，レ線学的 に，るいは radio isotope を用いた胃排出能の 観察があり, William and Barnes (1969) や Cowley (1972) らは Heineke-Mikulicz 型, Finney 型幽成ともに術後早期には胃内容の排 出遅延がみられ, 幽成の手術操作自体の影響が 大さいと述べている。李た，Davies (1974) ら は幽成によってっくられた新しい胃の stoma に郝忷る胃内容の排出動態は, stoma の大きさ に関係なく術後約 1 年で幽成型別の差はなくな り，とくに大きな胃の stomaを作製する必要は ないと報告している。本邦でも，白鳥(1968)や 田中（1974）は幽成により胃に拈ける逆蠕動性 放電様式の頻度が増加し，幽門がこの放電様式 の pace makerの様な役割をはたすと考光, 胃 運動機能面から考学るとさしろ幽門切除の方が 合理的であるとし，大井（1966），長尾（1975） らは幽成による静力学的な内容排出の増加は認 
めるが，蠕動性排出はむしろ減少するので逆蠕 動の抑制にはか党って逆効果であると述べてい る. 著者は幽門切除を含め幽成の術式別の今回 の実験から Heineke-Mikulicz 型幽成が筋電図 上もっとも変化が少なく, さらに手術操作の簡 便性などから本幽成術式を各迷切胃，横切胃に 付加して検討することにした。

一方, 消化管の運動機能の観察法としては, 今 回は筋電図学的検討と一部 barium study で胃 からの排出状態の観察を併用した。 犬の胃筋電 図では規則的な棘波型放電と，これにBozler (1945)のいう T wave が時折みられ幽門側へ伝 播する。空腹時の対照犬の胃前庭部の放電頻度 は Bozler (1954) や守谷 (1960) らはじめ諸家 の報告でも $4.9 \sim 5.7 \mathrm{cycle} / \mathrm{min}$ で今回の実験と 同様であったが，これに胃内容を負荷すると放 電頻度が減少することはすでに知られている。 また, 正蠕動性放電の減少は胃運動の減弱を表 わすと考兄られ，SVでは清水 (1975)らのよう にこの正蠕動性放電の減少による胃内容排出遅 延を述べる研究家が多く, SV 時には幽成の付 加が必要であると考兄られている。今回の実験 に括いても，SV群での胃内容負荷後の放電頻 度を経時的に観察した場合，幽成犬の方が非幽 成犬にくらべ放電頻度の安定性の面で優る結果 であった。 また野沢（1979）によれば，インス リン刺激による SV 犬の胃前庭部の運動機能の 低下から幽門洞枝の役割の存在も考慮すると, $\mathrm{SV}$ 時の胃運動機能低下に対する幽成の必要性 が示唆されて抢り，SVには幽成を必要とする という点では一致した見解が得られているとい える.

一方，SPV では，田中（1974）の報告と同様 に著者も幽成付加時の胃内容負荷後の経時的な 放電頻度の推移が対照犬に類似するという結果 を得たが，益子（1981）は対照でも胃体部にく らべて少ない胃前庭部の放電頻度が, SPV によ り減少し，これに幽成を付加することによりさ らに減少することから SPV 時の幽成付加は不 要であると報告しているょうに, SPV 時の幽成 付加の必要性については放電頻度の面からの検 討に限ると意見の別れるところである。著者は,
SPV 群の胃前庭部の放電頻度の検討からは, 空 腹時, 胃内容負荷直後の非幽成, 幽成犬の差異 は認めないものの，それ以降の経時的観察では SPV 時の幽成付加が胃運動機能保持にとって より有利であると考兄られている。

横切下部胃の異常運動は, 白鳥ら（1969）が 迷切に起因するものではなく，横切すること自 体による結果子報告し, 桑田 (1983) は, この 異常運動が内容の排出障害をひき抢こし, 幽成 を加えることにより胃運動機能の安定性が得ら れたとしているが，今回の著者の実験では, 横 切時の胃に抢ける幽成ではこのような効果は認 められず，横切による筋の連続性の遮断による BER 頻度の減少と考光た. 胃の活動電位を筋電 図パターンでみると，時に幽門側より噴門側へ 向う興奮伝播様式がみられ, 白鳥 (1959) はこ れを逆蠕動性放電と呼びその頻度は正常対照犬 でも高いもので $7.4 \%$ （清水，1975）という報告 もあるが，多くは $1 \%$ 前後（野沢，1979）で著 者の実験成績では $2.26 \%$ とほぼ同様であった。

迷切後の胃内容排出障害について, 白鳥 （1968）は，迷切が胃アトニーを生じ内容停滞と 内圧六進が生じ, これが痤攣様異常運動拈よび 逆蠕動をもたらし，さらに胃の内容排出障害を 来たすと報告している。田中(1974), 清水(1975) らは, 逆蝡動性伝播様式が空腹時, SV で対照の 約 4 倍, SPV では約 2 倍の頻度で発現すると報 告しているょうに, SPV 時の逆蝡動性伝播様式 の発現率は SV 時にくらべ低率というものが多 い.この逆蠕動性伝播様式については前述のよ らに白鳥 (1965) は, 幽門が逆蠕動の pace maker となると考兄られるで, 幽成よりも幽 切がより合目的な術式と述べているが，著者ら の実験ではSPV+幽成群で空腹時にこの逆蠕 動性伝播様式がより高率に発現するという特異 的な所見がみられた。 その根拠については定か ではないが，術後の瘢痕など幽門部の器質的変 化は迷切の場合には共通する要因と思われた。 しかし, 胃内容負荷により対照群やSV 群と同 様に逆蠕動性伝播様式が減少あるいは消失した 所見が得られ，胃内容負荷時には幽成によるそ のような影響は少ないと考えた。 
横切下部胃の逆蠕動性伝播様式の発現率は, 白鳥（1963），槙（1965），岡林（1967）らの報 告にもみられるようにかなり高く約 30〜 $50 \%$ で著者の成績でも同様であった。槇ら(1965)は， この横切時の逆蝡動性伝播様式の発現率は幽成 を加觉ることにより減少し正蠕動が増加すると 報告し, 桑田（1983） も横切時の幽成による胃 の異常運動の抑制について述べているが，古根 川（1978）は横切時の幽成付加によるこの伝播 様式の発現率に変化はないとして扮り，著者の 成績でも同様であった。

次に，胃と十二指腸の電気的活動の関連性に ついてみると，まずAllen and Davenport (1966)がはじめて胃の basic electrical rhythm （BER）が十二指腸起始部まで記録されたこと を報告している. Alvarez (1923) や Rosenbaum（1968）らのように胃と十二指腸間にわず かに存在する縦走筋線維を介して胃から十二指 腸へ伝播するという説や, Daniel (1963)らの神 経伝播説などがあり胃と十二指腸の間には蠕動 について何らかの関連が久られるとする報告も 多い。しかし一方で, Code (1952) やBass （1961）は筋電図上この関連を認めず，Reinke （1967）らも幽門部の解剖学的見解と mechanogram の所見から volume conduction 説を唱光 ている研究家もいる。本邦に扮いても，この関 連に関する研究は多く, 豊原（1973）も実験例 の $50 \%$ 以上にこの関連が夕られるとし, 著者の 実験でも実験例の 55.1\% に関連がみられほぼ 同様の結果であった。しかし，これら胃と十二 指腸の関連のみられるものでは，迷切時のよう な胃運動の抑制状態下ではこの関連の頻度は減 少するが，横切時のような胃運動の亢進時には 関連頻度が増加するとも報して扮り著者の成績 とは対称的な結果であった。松原(1976)は，胃 と十二指腸の関連は胃内容負荷によって増加す ると述べているが，今回，著者の実験でも幽成 を付加した迷切群と横切群に胃内容負荷時の関 連の増加する傾向がみられた。これは幽門洞枝 切離による胃前庭部の運動が抑制された SVで
は幽成付加により胃内容の静力学的排出がやや 促進し，十二指腸への流出，直接刺激によって 両者の関連が増加したが，胃前庭部の運動機能 が温存された SPVでは, 蠕動性排出に加光, 幽 成による静力学的排出によって胃と十二指腸の 関連が SV の場合より増加しているものと考克 られる。しかし，胃の異常運動が頻発する胃横 切時には，蠕動性排出よりむしろ幽成による静 力学的排出の増加にもとづく胃内容の排出が考 兄らる。

つぎにX線学的に消化管の運動を検討したの は Cannon（1898）に始まり，その後 Rieder （1911）が健康人の胃内容の十二指腸への排出時 間（GET）は 1 2 時間であることを報告した。

SV 胃については Griffth ら (1957) が, SPV 胃については Klempa ら（1971）がそれぞれ幽 成付加による GET の短縮について報告してい るが，今回の実験では, 対照にくらべ迷切群に GET の遅延がみられたが，幽成による GET の 短縮は SPV 時が SV 時に優る結果であった。 一方，田中ら(1974)は，流動食負荷の場合，幽 成付加 SV 犬が正常パターンに近づくものの, 固形食ではSPV 幽成付加犬が正常パターンに 近づくと報告しているように摂取内容を考慮す る場合, 胃内への負荷材料の種類といら観点か ら実験を追加する必要があると思われるので今 後の課題とした。

胃横切時，著者の実験で，非幽成，幽成群と もに GET は対照にくらべかなり延長したが， Nissen (1952) は人の胃横切時のX線学的検討 で，胃体部の atonic state と胃幽門洞部の spastic state が相まって胃内容の排出障害を生じる と報告している，横切時のこれら胃内容排出障 害に対する幽成のドレナージ効果についてX線 学的に検討した研究は少ないが，胃内容排出障 害が将来的には潰瘍形成の危険率の上昇につな がることを考光併せると，迷切時と同様，幽成 は有用は外科的対策のひとつといらことができ る。 


\section{V. ま と}

幽成と胃十二指腸運動機能との関係について 筋電図学的, X線学的に検討し, 次のような所 見が得られた。

1. 幽成では Heineke-Mikulicz 型幽成が筋 電図学的にみて変化が少なかった。

2. 幽成は, 空腹時の胃前庭部の放電頻度に 対して影響を及ぼさない。

3. 胃内容負荷時

（i） SVでは，放電頻度，興奮伝播様式扔よ びGET 観察上，幽成によるドレナージ効果が 示唆された。

（ii） SPVの場合には，幽成に打ける放電頻 度の有意変動はみとめられず, GET 観察上から も幽成のドレナージ効果はみとめられなかっ た。

（iii）横切犬に打いて頻発する逆蠕動性放電 は幽成を付加しても修正されなかった。

4. SPVでは, 幽成により空腹時の逆蠕動性
放電の頻度が増加する所見が特異的であった。

5. 幽成は SV, 横切時には胃前庭部と十二 指腸の同期的スパイク放電の頻度を減少した が，SPVでは増加する傾向を示した。

6. 以上の所見から SV，横切時には幽成を 付加することの有意性が筋電図学的にみとめら れた. SPVに対しては, 幽成付加の必要性につ いて有意義な所見にとぼしかったが，今後，迷 切が完全になされているか否かの判定法あるい は, 幽成の胃十二指腸運動への影響について,さ らには胃内容負荷物の種類による変化などにつ いて検討を重齐ていく必要があると思われた。

稿を終るに臨み, ご指導とご校閲を賜った継行男教授 に深甚なる謝意を棒げるとともに, 終始直接ご指導, ご 教授下さった小沢哲郎助教授, 龍礼之助元講師に深謝 し，また，研究にあたりご協力をいただいた教室諸兄に 心から感謝の意を表します。

\section{文}

Allen, G.L., Poole, E.W. \& Code, C.F. (1964). Relationship between electrical activities of antrum and duodenum. Amer. J. physiol. 207: 906-910.

Alvarez, W.C. \& Mahoney, L.C. (1923). The relations between gastric and duodenal peristalsis. Amer. J. Physiol. 64 : 371-386.

Amdrup, B.M. \& Giriffth, C.A. (1969). Selective vagotomy of the parietal cell mass. Ann. Surg. $170: 207-214$.

Bass, P., Code, C.F. \& Lambert, E.H. (1961). Electrical activity of gastroduodenal junction. Amer. J. Physiol. 201 : 587-592.

Bozler, E. (1945). The action potentials of the stomach. Amer. J. Phyiiol. 144: 693-700.

Cannon, W.B. (1898). The movement of the stomach studied by means of the Röntgen rays. Amer. J. Physiol. 1 : 359.

Cobb, J.C., et al. (1971). Gastric emptying after vagotomy and pyloroplasty relation to some postoperative sequelae. Digest. Disease. 16 : 207-215.

Collins, E.N. et al. (1948). Follow up of vagotomy plus gastroenterostomy or pyloroplasty for ulcer. Gastroenterology. 11 : 453-456.

Cowley, D.J., Vernon, P., Jones, T., Glass, H.I. and Cox, A.G. (1972). Gastric emptying of solid meals after truncal vagotomy and pyloroplasty in human subjects. Gut. 13: 176-181.

Daniel, E.E. et al. (1963). Electrical activity of the gastrointestinal tract as an indication of mechanical activity. Amer. J. Digest. Disease. 8 : 54-102.

Davenport, H.W. (1966). Physiology of the digestive tract. 2nd ed., Yr.Bk. Pub. Chicago.

Davis, W.T., Griffth, G.H., Owen, G.M. and Sihelds, R. (1974). The effect of vagotomy and drainage operations on the rate of gastric emptying in duodenal ulcer patients. Br. J. Sur. 61 : 509515. 
Dragstedt, L.R. (1945). Vagotomy for gastroduodenal ulcer. Ann. Surg. 122 : 973-989.

Ferguson D.J. et al. (1960). Segmental gastrectomy with innervated antrum for duodenal ulcer. Surg. $47: 548-556$.

Franksson, C. (1948). Selective abdominal vagotomy. Acta. Chir. Scand. 96: 409-412.

Griffth, C.A. and Harkins, H.N. (1957). Partial gastric vagotomy; an experimental study. Gastroenterology, $32: 96-102$.

H.J. Sheiner et al. (1980). Gastric motility and emptying in normal and post-vagotomy subjects. Gut 21 : 753-759.

Holle, E.F., Hart, W. (1967). Neue Wege der Chirugie des Gastroduodenalulkus. Med. Kin. 62 : 441-450.

金泉年郁ら (1982). 選択的近位迷走神経切離術後の胃内容排出動態の変化. 日平滑筋誌 18：331-338.

Klempa, I., et al. (1971). The effect of selective proximal vagotmy and pyloroplasty on gastric secretion and motility in the dog. Arch. Surg. 103: 713-719.

古根川龍司 (1978). イヌ胃に抢ける近側胃切除術後の筋電図学研究. 日平滑筋誌 14: 29-41.

桑島輝夫 (1977). 各種迷切のイヌ胃運動機能に及ぼす影響についての研究. 日平滑筋誌 13: 55-67.

桑田博文 (1983). 分節的胃切除術の幽門洞枝温存の意義についての実験的研究. 胃横切・端々吻合術術後 1 年の空腹時筋電図。日消外会 16: 943-952.

梖 哲夫 (1965). 近側胃切除をめぐる 2, 3 の問願. 治療 47: 789-793.

益子 博 (1981). 選択的近位迷走神経切離術に対する幽門形成術付加の効果に関する筋電図学的研究(犬). 日平滑筋誌， $17: 115-130$.

宮島良征 (1979). 選択的近位迷走神経切断後の胃運動機能に関する実験的研究. 日平滑筋誌 15: 51-64. 守谷 明 (1960). 胃の筋電図学的研究。東北医誌 62: 80-82.

長尾房大, 田中直樹 (1975). 迷走神経切離術と胃運動機能について. 臨床と研究 52: 132-137.

Nissen, V.R. (1952). Funktionelle und organische Störungen nach gastro-osöphagealen Anastmosen. Helvet. Chir. Acta. 19 : 314-323.

野沢晃一(1979). 同一犬に打ける各種迷切術前後の筋電図学的变化に関する研究-笳電図測定装置の改良も 含めて一。 日消外会誌 12:522-533.

大井 実 (1957). 胃潰瘍症. 南江堂. 東京.

大井 実 (1963). 胃運動機能に関する筋電図学的研究. 外科 25：1333-1342.

大井 実ら (1966)。幽門機能について-幽門形成術掞よび幽門筋切離術の意義一. 外科 28：(1326-1332.

岡林敏彦 (1967)。胃横切離の幽門機能に拈よぼす影響. 日平滑笳誌 3: 70-79.

Reinke, D.A., Rosenbaum, A.H. \& Bennett, D.R. (1967). Patterns of dog gastrointestinal contractile activity monitored in vivo with extraluminal force transducers. Amer. J. Dig. Dis. New series. 12 : 113-141.

Ritvo, M. and Shauffer, L.A. (1948). Roentgenographic studies of the gastrointestinal tract following section of the vagus nerves for peptic ulcer. New Eng. J. Med. 238: 496-510.

清水保雄 (1975). 迷走神経切断術後の胃運動異常に関する実験的研究. 日平滑筋誌 11: 55-77.

白石義光，及川俊彦（1984）。筋電図和上び収縮曲線の日内変動からみた犬の胃十二指腸間の関連。日平滑 筋誌 $20: 13-24$.

白鳥常雄ら (1959). 胃の筋電図学的研究. 東北医誌 60：885-891.

白鳥常雄 (1963). 消化管に括ける筋電図. 筋電図からみた胃の運動機能について. 日消病会誌 60: 990-992.

白鳥常雄, 籏福哲彦, 関根 毅(1965). 胃酸分泌領域に扣よぼす迷走神経支配の影響. 日平滑筋誌 1:223228.

白鳥常雄ら (1968). 迷走神経切離後の胃排出障害に関する実験的研究. 日平滑筋誌 4: 15-21.

白鳥常雄ら (1969). 横切離下部胃に扝ける運動機能の異常六進の原因に関する実験的研究. 日平滑筋誌 5 : 27-32.

白鳥常雄 (1984)。運動機能から見た胃の手術。日消外会誌 17 (3)：507-516.

Sugawara, K. (1964). An electromyographic study on the motility of canine stomach after transection and end-to-end anastomosis. Tohoku J. exp. Mec. 84 : 113-124. 
田北周平 (1970). Selective proximal vagotomy and partial anterectomy. 国際外科学会日本部会, 盛 岡.

田中直樹ら (1974)。迷走神経の胃運動に及ぽす影響に関する実験的研究一特に選択的迷走神経切断術と近 位選択的迷走神経切断術の意義について一。 日平滑筋誌 10:269-285.

Thomas, J.E. \& Crider, J.O. (1935). Rhythmic change in duodenal motility associated with gastric peristalsis. Amer. J. Physiol. 111: 124-129.

豊原一宇 (1973)。胃と十二指腸の関連についての筋電図学的研究。 日平滑筋誌 9: 123-136.

上西紀夫ら (1983)。高位潰瘍に対する選択的近位迷走神経切離兼分節的胃切除術の遠隔成績一とくにドレ ナージ術付加の問題点と関連して一. 日消外会誌 $16: 8-16$.

W.D. George et al. (1975). The effect of the size of the gastric outlet on gastric emptying after vagotomy for duodenal ulcer. Br. J. Surg. 62: 879-881.

Wangensteen, O.H. (1952). Segmental gastric resection for peptic ulcers. Method permitting restoperation of anatomic continuity. JAMA. 49: 18-32.

Williams, J.A. and Barnes, A.D. (1969). Postoperative gastric retention. In: Williams, J.A. and Cox, A.G. (ed) After vagotomy, ch. 14. London, Butter Worths, pp : 175-187.

Willkinson, A.R., et al. (1973). Effect of truncal, selective and highly selective vagotomy on gastric emptying and intestinal transit of a food-barium meal in man. Ann. Surg. 178: 190-193.

横路 洋ら (1976). 各種迷切術と胃筋電図. 日平滑筋誌 12: 15-24.

(1988 年 6 月 1 日受付) 